\title{
"VALUATION OF RAILWAY PROPERTY FOR PURPOSES OF RATE REGULATION",
}

The title of this paper is included within quotation marks because this or like form of words has been used recently to indicate the thought that value for the purpose of rate regulation is not value in its broadest sense. It is not to be understood that because of the use of that title the writer approves any such doctrine. To him it seems that the ascertainment of the value of a thing, whether it be a vacant lot or a railroad property, is the determination of a fact, and that the same property cannot be of two or more different values at one time.

In recent years the subject of valuation of railroad properties has received much attention. It is of some interest to note the circumstances which led up to railroad appraisals. In by far the larger part of the country railroads have been pioneers and have opened up the country by furnishing transportation facilities for the development of other enterprises. In the early days the people, especially in the newer states, felt great anxiety that railroads should be provided as an aid to future development; they held out inducements to persons having capital in order to persuade them to invest in railroads. That such means of transportation were necessary for the prosperity and upbuilding of the country was conceded by all; great and successful efforts were made to secure large subsidies in the way of land grants, free rights of way, aid bonds, and the like for railway companies; many cities, counties, and villages freely voted bonds to aid construction. Because railroads were necessary to open up undeveloped territory so that large wastes might be changed into populous regions, dotted with prosperous cities, thriving towns and villages, and occupied as fruitful agricultural areas, the people generally favored and encouraged them. Doubtless everyone will admit that no other enterprise has done so much for the development of the greater part of this country as have the railroads, and that it would be 
a great calamity if they were to be dealt with in such a way as to impair their usefulness as instruments of public service and progress. However, after reasonably adequate railroads had been provided, their patrons naturally desired transportation at the lowest rates consistent with the maintaining of efficiency and the retention of the advantages secured from railroad service, and many, without full consideration or sufficient knowledge of the facts, conceived that the companies, already possessing large capital, could at all times and under all circumstances furnish the means or command the credit necessary to discharge their many and increasing duties to the public.

There also existed a widespread belief that railroad carriers sought to maintain schedules of rates, not only sufficient to pay all operating expenses, including maintenance and taxes, besides a fair compensation for the use of the property employed in the public service, but also to pay interest upon bonds and dividends upon stock improvidently and extravagantly issued. State legislatures made many rate reductions which were so low that the companies brought suits in equity to have them set aside as confiscatory, because they would not permit a fair return upon the value of the property. It was thought in some states that railroads did not pay their fair share of taxes. Under these circumstances it was natural that a demand for valuation should be made. Perhaps the first effort to make a complete valuation of railroad property was in Michigan, about the year I9oo. This valuation was primarily for the purpose of taxation. Wisconsin, Minnesota, Washington, Texas, California, and other states have also undertaken railroad valuation for various purposes.

Until recently the reproduction method was insisted upon by the states as the best one for the ascertainment of the present value of railroad properties. In some instances at least the state appraisals have made it perfectly plain that existing schedules of rates were not high enough to maintain the property, pay operating expenses and taxes, and yield a fair return upon the value so ascertained; and since the failure of such appraisals to justify further rate reductions much diligence has been exercised on the part of many to find a lower basis of valuation. The cost of the 
property is now proposed by some, who undertake to speak for the public, as a substitute for, or the equivalent of, value.

It is clear that reliable knowledge concerning the value of railroad properties may be useful for various purposes; for example, as a basis for taxation, as a guide to investors in railroad securities, as an aid to the public control of the issuance of stock and bonds, as an aid to test the reasonableness of the general level of rates, and as a guide for further legislation. It is, however, a mistake to suppose that railroad rates are, or as a practical matter can be, made or based upon the value of the property used to render the service. By those who have given attention to the subject it is well understood that rates substantially depend upon many other considerations. Carriers between competitive points must maintain the same rates, and no shipper, locality, or class of traffic can be given any undue advantage or subjected to any undue disadvantage. The half-dozen or more railroads engaged in active competition for traffic moving between the Twin Cities and Chicago must establish and maintain the same rates. Rates from different sources of production of the same or like commodities to the markets therefor, or to the places where the same are consumed, must necessarily bear a certain relation to each other. The effect of the transportation upon the value of the thing moved, the value of the service to the shipper, the cost of the service to the carrier, the nature and extent of the risk involved, competition between carriers, places, and commodities, and many other circumstances must be taken into account in making rates. Rates made by the railroad companies themselves have never been based upon the value of the property employed to render the service, and rarely, if ever, has any public authority attempted to make rates based upon such value.

In recent years there have been many suits in court brought by railroad carriers to set aside state-made rates as unconstitutional and void because confiscatory. In such cases the value of the property used to render the service covered by the rates complained of may be an essential fact. It is, however, well known that rates may be high enough to be non-confiscatory and yet much below what is reasonable and just under all of the circumstances. Because 
of the nature of the business of common carriers and the interest of the public therein, the common law imposed the duty upon those engaged in it to serve all indifferently to the extent of their capacity, to answer strictly for the property intrusted to their care, to diligently transport and safely deliver, and they were bound to serve for a reasonable compensation. The customary price of like service was deemed to be the reasonable charge, and refusal to accept such rate, or the exaction of more, gave a cause of action for damages, or to recover back the amount of the charge in excess of the customary price or reasonable rate. ${ }^{\mathrm{I}}$

In an action at common law to recover an excess charge exacted by one engaged in a public service, no one ever knew of an inquiry as to the total profits of the party making the charge, or of a comparison of such profits with the value of his property employed to render the service, but the inquiry was to ascertain whether the particular charge was a reasonable exaction for the service. ${ }^{2}$ Doubtless it is because of the frequency of confiscation cases-in which the value of the property has been brought forward in support of the claim that legislative authority transgressed the limits of its power as fixed by the Constitution-that superficial opinion has grown up to the effect that rates are made or based upon value.

By far the most important undertaking in the work of valuation is the federal valuation of railroads now going on under an act of Congress approved March I, I9I3. The reasons for, and scope of, that act are of interest to everyone interested in railway problems. The value required to be ascertained is not for any particular purpose, though it may become involved in rate-making, in rate-judging, in taxation, in accounting, in capitalization, in public purchase, in sale of securities, and it may be used as a guide to future legislation. The title of the act shows that it is the purpose of the law to cause a "valuation" of the several classes of property of carriers. Value in its broadest sense is required to be found.

I II Kent's Comm. 599; Smith's Leading Cases, Vol. II, Part I, pp. 457 ff.

${ }^{2}$ Cotting v. Kansas City Stock Yards, 183 U.S. 79; Canada Southern Railway v. International Bridge Company before Privy Council, 8 App. Cases 723 (1883); Texas and Pacific Ry. v. Abilene Cotton Oil Co., 204 U.S. 426, 436. 
At the time of the passage of the law important rate cases were pending in the Supreme Court of the United States and the valuation approved by the lower courts in some of these cases was being publicly discussed with much interest; and inasmuch as the fundamental principles controlling valuation were not finally settled, Congress required the Interstate Commerce Commission, not only to ascertain value, but also to report in detail the facts necessary to apply various principles and theories of valuation then being contended for.

To illustrate the issues then pending, we call to mind the fact that attorneys, economists, and appraisers, assuming to speak for the public, vigorously contended for principles and methods of valuation of railroad property calculated to produce results much below real value. They have contended: (a) That a railroad company is not entitled to increments of value of any part or element of a railroad-land, embankment, or anything else-due to the enhancement of market price or to improvement by lapse of time; (b) that a railroad company is not entitled to a return upon the value of property acquired by the use of money given to it in aid of the enterprise, and is not entitled to any return upon property granted or donated to it as an inducement to build the railroad; (c) that a railroad company is not entitled to any return upon property paid for out of surplus earnings; $(d)$ that in rate cases the cost of the railroad property is the measure of value and constitutes the base upon which the company is entitled to a return; (e) that the value of the physical elements (excluding value arising from franchises, contract rights, etc., which were acquired without cost) is the maximum upon which a railroad company is entitled to a return, and that the value of such physical elements is measured by the cost of reproduction less depreciation; $(f)$ that railroad property is not in reality private property but that it is held by the owner as trustee for the benefit of the public. ${ }^{x}$

${ }^{1}$ Report of the Committee on Interstate Commerce United States Senate on House Bill 22593 (subsequent to the Federal Valuation Act), with hearings: statement of Judson C. Clements, p. 209; ibid., statement of Commissioner Balthasar H. Meyer, p. 230; ibid., statement of John R. Commons, pp. 84, 86, 87, 100, 101, 102, 107; Advance in Rates, Western Case, 20 I.C.C. Rep. 334, 337, 347; ibid., Eastern Case 269; Proceedings of the Twenty-fifth Annual Convention of the National Association of 
Notwithstanding that each of these propositions is without support in the decisions of the courts, they are still being urged in controversies concerning the reasonableness of rates, and undoubtedly these, and other claims having like purposes, will be urged upon the Interstate Commerce Commission as proper guides for the valuation of railroad property required by the act.

The passage of the valuation act was promoted, to some extent at least, by those who favor such propositions, and some of its requirements indicate that it was the purpose of Congress to provide, not only for the determination of value, but also to require the ascertainment of many facts and much information having more or less relation thereto for the purpose of disclosing the methods by which the value was ascertained, and to provide data for the application of whatever rules or principles of valuation might finally be adopted. It is clear that the federal valuation act does not contemplate that the Interstate Commerce Commission, or any of the state commissions, shall make rates based upon that value.

Railroad Commissioners, Washington, D.C., October 28-31, I9I3: paper by Max Thelen, California Railroad Commission, pp. 265, 27I, 275; ibid., paper of $\mathrm{Mr}$. Henshaw, Oklahoma Commission, pp. 282, 290; ibid., paper by Professor E. W. Bemis, pp. 309, 317, 322; ibid., statement of Mr. Clifford Thorne, Iowa Commission, citing many court decisions in rate cases holding that value of the property used, at the time that it is used, or present value, is the basis on which return is to be calculated, and opposing the view of Professor Bemis that the courts have shown that they do not mean value when the term "fair value" is used; ibid., statement of Mr. Duffy, of the American Railway Accounting Association, p. 338; ibid., statement of Mr. Echelman, of the California Commission, p. 338; ibid., paper by Mr. F. E. Barker, chairman of the Massachusetts Board of Gas and Electric Light Commissioners, p. 369; ibid., statement of Interstate Commerce Commissioner Daniels, p. 376; see statement of Professor E. W. Bemis before St. Paul City Council in Gas Case hearing in May, r914, at p. 40r, where he said in substance that in rate cases there is no such thing as value, but that "fair value," or "amount of property," or "fairness" is meant; see testimony of Professor Henry C. Adams in D.S.S. and A. Railway Passenger Rate Case, August I4, I9I3, pp. 5446 ff., where he said: "In my judgment this thing that we call value in practical questions is a thing to be gotten at in order to arrive at equitable conclusions between contending parties, and it is always necessary to know what the contention is and what the relative rights of the parties are in order to proceed in any analysis or definition of 'value.' "' On the assumption that terminal land bought in Chicago fifty years ago for $\$ 5,000$ is now worth $\$ 5,000,000$ he said that "the $\$ 5,000$ is the sum that ought to be included in what is called the value for determining the rate" (ibid., pp. 545 $\mathrm{I}-52$ ), and that "for taxation purposes that is taken at its present value" (ibid., p. 5453). See also The Valuation of Railroad Right of Way No. 3, by Hon. Frank W. Stevens, counsel for the New York Central Lines. 
As above pointed out, the value of railroad property may be used to ascertain whether or not the general level of rate schedules is too high or too low, and may be used in confiscation cases to determine whether legislative rates violate the Constitution. To this extent value of railroad property may be involved in or related to the regulation of rates.

Clearly the same principles govern valuation of railroad property for the purpose of rate regulation as apply in the case of condemnation of private property for public use.

A few years ago the statement of that proposition would have been universally accepted, not only as the settled law, but also as so manifestly just and reasonable as to require no support by the citation of authority or the statement of the reasons upon which it rests. Recently, however, as above indicated, the value of railroad property has been attacked in the field of public discussion and in the courts, and men of prominence propose definitions of value which lead directly to the conclusion that legislative authority may be arbitrarily exercised in prescribing railroad rates and charges. In other words, the various conceptions and definitions of value being put forward as sound will, if accepted, set at naught the Fifth and Fourteenth Amendments, protecting private property against seizure for public use without just compensation. A mere moral obligation to be "fair" or "just" or to seek an "equitable conclusion" would be substituted for our most important constitutional provisions. Notwithstanding governmental power to regulate its use, railroad property is private property, and its owner is entitled to compensation for its use in the public service and to have and enjoy whatever profit can be secured by the application of a just and reasonable schedule of rates, and no power may justly require the use of such property without reasonable reward. It is familiar law that the Constitution protects the owner in the right, which legislative authority cannot take away, to earn a reasonable rate of return upon full value of the property used, as that value is, at the time that it is used in the public service, subject only to the limitation that rates shall not be extortionate or excessive.

Railroad business is subject to many risks and hazards. No one gives assurance that there will be any net earnings or that 
property invested in the enterprise will not be lost. If the owner of railroad property makes a mistake, he alone must bear the consequences, and justice requires that if he builds wisely his intelligence and enterprise should be rewarded.

Admitting the power so to do, it would not be just to reduce rates below what is reasonable merely because the profits of the company are large. A railroad may be so fortunately circumstanced that it can earn large profits at reasonable or even low rates. It is only when railroad property is well located, built to meet a reasonable demand for its service, intelligently planned, economically constructed, maintained, and operated, that its owner is, as a matter of constitutional right, entitled to a reasonable rate of return upon the value of such property. But will it not be conceded that the mere existence of legislative power to reduce rates does not justify the exercise of that power? Should all the rewards which are due to the foresight, wisdom, and enterprise of the men who conceived and constructed wisely be transferred by legislative authority to others?

The substitution of cost for value and the making of rates on that basis would unjustly deny reward and profit to the owners of the best railroads of the country and amount to seizure of the use of private property without just compensation.

It may be worth while very briefly to call attention to some of the reasons why no such thing can be done.

In case of the taking of private property for public use by the exercise of the power of eminent domain, it is conceded by everyone that the owner of the property taken is entitled to the full market value thereof, and, as a part of his compensation, he is also entitled to the damages proximately resulting to his other property. It will not be claimed that legislative authority has any power to prescribe the amount of compensation to be paid for property so taken, and it is well understood that all the elements of value existing at the time of the taking must be ascertained and paid for.

The Fifth Amendment to the Constitution of the United States contains language as follows: "Nor shall private property be taken for public use without just compensation." The Fourteenth Amendment contains the following: "Nor shall any state 
deprive any person of life, liberty, or property, without due process of law; nor deny to any person within its jurisdiction the equal protection of the laws."

The Fifth Amendment is a limitation upon the power of Congress and its equivalent is found in all state constitutions. It prevents the seizure or condemnation of private property without just compensation; under it, Congress has no power to make and enforce railroad rates so unreasonable and low as not to yield a fair return upon the full value of the property. Thus the very same words of the Constitution prohibit confiscation by rate-making as prohibit the actual seizure of property for public use without just compensation. The above provision of the Fourteenth Amendment prohibits confiscation by state-made rates. These constitutional provisions have been held applicable in rate cases by the Supreme Court on many occasions during the last quarter of a century.

In rate cases, as well as in condemnation cases, all values and elements of value must be taken into account and included. ${ }^{\mathrm{I}}$

The suggestion that there exists between the public and each railroad carrier the relation of principal and agent, or beneficiary and trustee, is without foundation. The public does not owe the company the money that the latter has invested in the railroad property; if a loss or profit results from the conduct of the enterprise it must be borne by, or belongs to, the carrier, and the public, having no obligation to reimburse in case of failure, may not

${ }^{1}$ National Water Works Co. v. City, 62 Fed. 865; Omaha v. Omaha Water Company, 218 U.S. 180; Brunswick Dist. v. Main Water Co., 59 Atl. 537; City of Knoxville v. Knoxville Water Co., 212 U.S. I; Cedar Rapids Gas Light Co. v. Cedar Rapids, 223 U.S. 655; Gloucester Water Supply Co. v. City of Gloucester, I79 Mass. 365, 60 N.E. 977; Newburyport Water Co. v. Newburyport, I68 Mass. 548, 47 N.E. 533; Spring Valley Water Works Co. v. City of San Francisco, I24 Fed. 574; Norwich Gas and Electric Co. v. City of Norwich, 57 Atl. 746; Galena Water Co. v. City of Galena, 87 Pac. 735; Venner Co. v. Urbana Water Works, I74 Fed. 349; Missouri, Kansas and Texas Ry. Co. v. Love, I 77 Fed. 493; Cedar Rapids Water Co. v. Cedar Rapids, II 8 Iowa 250; Des Moines Water Co. v. City of Des Moines, I92 Fed. 193; Des Moines Gas Co. v. City of Des Moines, 199 Fed. 204; Pioneer Tel. and Tel. Co. v. Westenhaver, I18 Pac. 354; People ex rel. Kings County Lighting Co. v. Willcox, ro4 N.E. 9ri; Public Service Gas Co. v. Board of Public Utility Commissioners, 87 Atl. 651; Spokane v. Northern Pacific Railway Co., I5 I.C.C. Rep. 376; Bonbright v. Geary, 2 ro Fed. 44; Monongahela Navigation Co. v. U.S., I48 U.S. 3 I 2. 
appropriate the rewards of success. The title to railroad property is not held either in whole or in part for the use or benefit of the public. The company has the full title and ownership.

By repeated decisions of the Supreme Court of the United States it has been held that railroads are the private property of their owners; that, while from the character of the work in which they are engaged public authority has power to regulate the use of the property in certain particulars, it is in no sense the owner of the property or of any interest therein, and that, subject to the limitations that charges shall not be unjust or unreasonable, and that they shall not discriminate, railroad companies are as free to manage their important interests as those engaged in other callings. ${ }^{\text {. }}$

From the very beginning of the exercise of the power of the states to prescribe the charges of those engaged in public callings it has been held to be within the scope of judicial power, and a part of judicial duty, to restrain and set aside any measure which operates to deny to the owners of property used that equal protection which is the constitutional right of all owners of other property, and that, in such matters, the limitation upon the power of states prescribed by the Fourteenth Amendment is the equivalent of that upon the power of Congress prescribed by the Fifth Amendment, and that these constitutional provisions forbid legislation, in whatever form it may be enacted, by which the property of one individual is, without compensation, wrested from him for the benefit of another or the public. In one case the Supreme Court said:

This, as has been often observed, is a government of law, and not a government of men, and it must never be forgotten that under such a government, with its constitutional limitations and guarantees, the forms of law and the machinery of government, with all their reach and power, must in their actual workings stop on the hither side of the unnecessary and uncompensated taking or destruction of any private property, legally acquired and legally held. ${ }^{2}$

In answer to the suggestion that the prescribing of rates is a mere regulation and not the taking of property it was said:

The equal protection of the laws-the spirit of common justice-forbids that one class should by law be compelled to suffer loss that others may make

I Interstate Commerce Commission v. Chicago Great Western Railway Company, 209 U.S. 108, 118.

${ }^{2}$ Reagan v. Farmers' Loan and Trust Company, I54 U.S. 363, 399. 
gain. If the state were to seek to acquire the title to these roads, under its power of eminent domain, is there any doubt that constitutional provisions would require the payment to the corporation of just compensation, that compensation being the value of the property as it stood in the markets of the world, and not as prescribed by an act of the legislature? Is it any less a departure from the obligations of justice to seek to take, not the title, but the use, for the public benefit at less than its market value ? ${ }^{\mathbf{x}}$

\section{Again it was said:}

Property invested in railroads is as much protected from public appropriation as any other. If taken for public uses its value must be paid for. Constitutional guaranties to this extent are explicit; and in such condemnation proceedings no inquiry is permitted as to how the owners have acquired the property, provided only it be legally held by them. If a farm belongs to an individual, and the public seeks to take it, it must pay its value, and is not permitted to diminish the price by proving the owner acquired the means of purchase by immoral or disreputable practices. He may have made his fortune dealing in slaves, as a lobbyist, or in any other way obnoxious to public condemnation; but if he has acquired the legal title to the property he is protected in its possession, and cannot be disturbed until the receipt of its actual cash value. The same rule controls if railroad property is sought to be appropriated. No inquiry is open as to whether the owner has received gifts from state or individuals, or whether he has, as owner, managed the property well or ill, or so as to acquire a large fortune therefrom. It is enough that he owns the property-has the legal title; and, so owning, he must be paid the actual value of that property. If he has done any wrong in acquiring or using the property, that wrong must be redressed in a direct action therefor, and cannot be made a factor in condemnation proceedings. These propositions in respect to condemnation proceedings are so well settled that no one ever questions them. The same general ideas must enter into and control legislation of the kind before us. The value of the property cannot be destroyed by legislation depriving the owner of adequate compensation. ${ }^{2} \ldots$. .

Now, if the public was seeking to take title to the railroad by condemnation, the present value of the property, and not the cost, is that which [it] would have to pay. ${ }^{3}$

The language above quoted is that of Mr. Justice Brewer in decisions handed down in I894. Since then the same doctrine has been applied by the Supreme Court of the United States over and over again. ${ }^{4}$

× Ibid. 410.

${ }^{2}$ Ames v. Union Pacific Railway Company, 64 Fed. 165, I76.

${ }^{3}$ Ibid. 177 .

4 Smyth v. Ames, 169 U.S. 466 (1898); San Diego Land and Town Co. v. National City, 174 U.S. 739 (1899); San Diego Land and Town Co. v. Jasper, I89 U.S. 439 (1903); Stanislaus Co. v. San Joaquin Co., 192 U.S. 20I (1904); City of Knoxville 
In the Minnesota rate cases counsel for the state directly urged:

(a) Where right of way has been donated free of cost it should not be included in the aggregate amount upon which to base a return; (b) that the land secured under the right of eminent domain should never be valued at more than original cost; and also in effect $(c)$ that additions or extensions paid for out of earnings should not be included in the value of the property.

The Court decided the case June 9, I9I3, and made this very definite statement.

It is clear that in ascertaining the present value we are not limited to the consideration of the amount of the actual investment. If that has been reckless or improvident, losses may be sustained which the community does not underwrite. As the company may not be protected in its actual investment, if the value of its property be plainly less, so the making of a just return for the use of the property involves the recognition of its fair value if it be more than its cost. The property is held in private ownership and it is that property, and not the original cost of it, of which the owner may not be deprived without due process of law. ${ }^{\mathrm{x}}$

Some who encourage constant and frequent rate reductions through the exercise of legislative power suggest that the court has not meant what it said; that the word "value" as used in a long and unbroken line of decisions was intended to mean something else-something less-and they call attention to the expressions "fair value," "reasonable value," and the like in support of that idea. Their thought seems to be that it would be "fair" and "reasonable" to take private property-in the use of which the public generally has an interest-from the owners thereof, if it cost less than its present value, or if it was paid for in whole or in part out of earnings that might have been divided among the stockholders in the enterprise.

It is certain that these phrases were never intended to be so used or understood. It might with equal reason be said that the phrase "just compensation," as used in the Fifth Amendment, which has come down to us from Magna Charta, does not mean

v. Knoxville Water Co., 2 I 2 U.S. I (I909); Willcox v. Consolidated Gas Co., 2 I 2 U.S. I9 (I909); Minnesota Rate Cases, 230 U.S. 352 (I913); San Joaquin Company v. Stanislaus County, 233 U.S. 454 (19I4).

I Minnesota Rate Cases, 230 U.S. 352, 454. 
compensation, including the value of the property taken and the damages resulting from the taking; that in case of government grants of lands to settlers, free or for a small consideration, it would be "just" under the Constitution to permit it to be taken for a post-office site at what it cost the owner, or at what it cost less the value of its use while he had it, because he always held it subject to be taken for public use upon payment, not of "compensation," but of "just compensation." But as against contentions of like character it is well established that the word "just" is used evidently to intensify the meaning of the word "compensation," to convey the idea that the equivalent to be rendered for property taken shall be real, substantial, full, and ample; and that no legislature can diminish by one jot this rotund expression of the Constitution. ${ }^{\mathbf{x}}$

It must be considered as established by highest authority, beyond doubt in confiscation cases, that the value of the property must be taken as it is at the time it is being used to perform the service covered by the rates in question, and that the rate schedules cannot be reduced by legislative authority below what is sufficient to permit the earning of a full and fair rate of return upon that value. It is also true that a rate which is merely high enough to be adjudged non-confiscatory when attacked in judicial proceedings may be much below what is reasonable and just under all the circumstances.

Many considerations suggest the wisdom and justice of allowing railway carriers liberal and generous rates. In territories that are not fully developed much uncertainty as to the volume and constancy of the flow of traffic exists; it is always desirable that railway companies be able and ready to meet the maximum demand, and, therefore, much larger investment in land, structures, and equipment is required in the case of irregular business moving fitfully than would be required if the same moved with regularity; in all parts of the country increasing demands for service require expensive improvements and extensions; the money required to pay for them must be secured from the sale of bonds or stock subscriptions; it is manifest that if the margin of safety is small,

${ }^{x}$ Lewis, Eminent Domain, 3 d ed., sec. 684, and cases cited. 
rates of interest and discount upon bonds will be high, and that new stock will not be subscribed for at par unless present outstanding stock is worth something more than par and reasonable dividends on the total are quite certain to be paid; a very large volume of securities against the railroad properties of this country are held as investments for trust funds and the savings of the people; confidence and credit cannot be established nor maintained unless present and prospective earnings are sufficient to leave a substantial surplus in good times that default may not occur in periods of depression; sound policy requires that the well-located and economically managed railroads of the country be allowed a schedule of rates sufficient to produce a surplus to pay for nonrevenue-producing improvements - such as attractive passenger stations and grounds, provided, not as necessary facilities, but to keep step and correspond with the advancing tastes and ambitions of every growing city; the elimination of crossings at grade in the interest of safety; the lessening of noise and smoke in the interest of public health and comfort, and many other things of similar character. Railway owners and managers are, as a general rule, in full sympathy with all reasonable demands of the public in these matters and respond to them to the extent of their ability, but it is plain that, if additional securities must be issued to make improvements of this class, the margin of safety will grow less all the time, and fixed charges constantly advancing will impair the credit of securities as investments.

Current statistics and a multitude of facts which are generally known to those interested in railroads might be brought forward to illustrate and emphasize the necessity of rate allowances generously above what is required to pay a fair rate of interest on the present value of the property. The policy should be to strengthen and not to strain credit; sparingly to issue additional securities in order that the same may be salable at desirable rates, and that those which have been legitimately issued and now in the hands of the public may be strengthened and made perfectly safe.

As value is not to be arrived at by rules or formulae, but in the exercise of sound judgment formed in the light of all the facts, it is obvious that only men of experience, intelligence, and perfect 
fairness are qualified to do this work well. It is difficult to think of a calamity so great as that which is certain to follow a valuation based upon the theory that the federal Constitution does not protect the full present value of railroad property in rate regulation, and that individual conceptions of right and wrong may be substituted for fundamental principles of organic law.

Proper valuation of the railroads will furnish information which may be used to ascertain the reasonableness of the general level of rates in broad areas, and to support appropriate readjustments thereof. If, by means of it, a better public sentiment will be created-and it is thought that this will result if the work be well done-so that the carriers will be permitted to have rates which are justified by an enlightened and sound public policy, the enormous expenditures now being made by the government and by the carriers will be fully warranted.

The reasonableness of the rate of return to be allowed on present value is of great importance. While that question is not directly involved in valuation it is so closely related to regulation that a few words here with reference to it will not be out of place.

While the determination of what is a reasonable rate of return cannot be made with accuracy, but is a matter for judgment based on all the circumstances, certain considerations are recognized as having a definite bearing upon the matter. It is impossible that rates on different roads in the same general territory should vary widely; each must meet the rates of the others, and a schedule that will permit a generous return upon the value of one may be ruinous to another; therefore it is impossible that rates of return upon different properties shall be the same, or even approximately so.

The most favored road must be allowed a generously high return or many others will fail. The circumstances of all in the same general territory must be taken into account. Few roads, if any, will be found which may be destroyed without great injury to the public, and assuming that the existence of a railroad property is desirable or justified at all, it is surely entitled to earn-if it can do so at rates which are not per se extortionate-a rate of return upon the full present value of its property at least as high as the 
legal rate of interest. This being so, it necessarily follows that the strong lines must have a rate of return considerably higher than that.

In recent periods the net earnings on capital and surplus of national banks averaged from $8 \frac{1}{2}$ to Io per cent per annum. It is a general rule that, other things being equal, the rates demanded for investments are greater where risk and uncertainty are greater. It probably will not be suggested by anyone that the risk attending the business of national banks is as great as that attending railroad business. The bank selects its borrowers and securities, and may, if business becomes unprofitable, withdraw from it and invest its money elsewhere; its return is regular and certain; it is paid for the use of capital alone, and no considerable element of labor or management enters into the production of the result.

It is manifest that new capital will not seek railroad investment if it be prohibited from earning therein as much as is generally earned in other large enterprises where the danger of loss, or of no return, or of irregular return, is no greater than in the railroad business; and if new capital cannot be secured to furnish additional mileage and facilities the result to all concerned will be serious.

While it is undoubtedly true that money invested in railroads generally has not in the past yielded as high a rate of return as other large investments, yet, until recent years, the prospect of increasing returns with the development of the country and the rise in the market value of railroad securities operated as an inducement to attract capital to the railroads. Of late years, however, conditions have not invited but have repelled such investments, and therefore the return, to be reasonable, must be higher and more certain than it has been recently or is at present.

In summarizing the foregoing, then, we may emphasize the following points: First, as a practical matter rates cannot be made or based upon value. Value of the property is an essential fact in rate cases involving the question of confiscation, but a rate only high enough to be non-confiscatory may be much below what is reasonable. The same principles govern valuation of railroad property for the purposes of rate regulation as apply in the case of condemnation of private property for public use; and the same 
constitutional provisions which prohibit the condemnation of private property for public use without just compensation prohibit the taking of the use of the property by imposing rates that are unreasonably low and confiscatory. In both cases all values and elements of value must be included. "Reasonable value" means value, and "just compensation" means real, substantial, full, and ample compensation. Second, it has been the frequency of confiscation cases in which the value of the property has been an important test that has given rise to superficial opinion that rates are based upon value. Third, there is no foundation for the suggestion that there exists between the public and each railroad carrier the relation of principal and agent, or beneficiary and trustee. It is settled by repeated decisions of the Supreme Court of the United States that railroads are the private property of their owners, subject to regulation that charges shall not be excessive or unequal. Fourth, a proper valuation of the railroads, such as that authorized by the federal valuation act, will furnish a guide to ascertain the reasonableness of the general level of rates in broad areas and to support readjustments thereof. Railroad rates ought not to be reduced as low as possible without confiscation; in fact many considerations suggest the wisdom of allowing railway carriers liberal and generous rates. The rate of return is definitely involved in confiscation cases and is related to rate regulation. New capital will not seek railroad investment if prohibited from earning as much as is paid in other large investments where the risk is no greater. Prospects of increasing returns and of rise in the market value of railroad securities formerly attracted capital to railroads, but conditions lately have not encouraged such investments.

St. Paul, Minn.

Pierce Butler 